\title{
TURBIDITE DEPOSITION IN THE EARLY LATE CRETACEOUS PINDOS BASIN (EXTERNAL HELLENIDES)
}

\section{P. NEUMANN ${ }^{1}$}

\begin{abstract}
The lower Upper Cretaceous clastic lithologies of the Pindos Zone in western Greece document a phase of enhanced tectonism. They are preserved as mixed carbonate/siliciclastic turbidite associations alternating with deep-marine siliceous sediments. New faunal and sedimentological data recovered from these deposits hint at two major pulses of turbidite shedding commencing at the change from the Early to the Middle Cenomanian and in the Late Turonian. The deposits are organized in generally thin clastic packages that can be attributed to lower fan facies. Different sources are likely for the occurrences in the central Pindos Mountains, the western and the easternmost Peloponnese.
\end{abstract}

KEY WORDS: Cretaceous; turbidite facies; submarine fans; Pindos Basin; biostratigraphy; orbitolines; Greece.

\section{INTRODUCTION}

In the Mediterranean Tethys, the Mid-Cretaceous interval records a complex evolution characterized by breccias, flysch-like deposits, facies changes, slumps and black shales (e.g. Galli 1993; Gusic \& Jelaska, 1993). Mid-Cretaceous strata in different zones of the Greek Hellenides closely mirror this complex history of tectonic and sea-level controlled processes.

The Pindos Zone is a major nappe unit in western Greece exposing thrust-imbricated sedimentary rocks. These originate from a deep, probably oceanic, basin (e.g. Degnan \& Robertson 1998) that formed along the northeastern passive continental margin of Apulia in Mesozoic to Tertiary times (e.g. Dercourt et al., 1993). The Mid-Cretaceous basin fill comprises thin siliceous sediments (Marnes rouges; Fleury, 1980; Thiebault et al., 1981), siliciclastic facies (Premier flysch du Pinde; Aubouin, 1957; Fleury, 1975), orbitoline-rich calciturbidites (Orbitolinenhorizont sensu Renz, 1955) and black shales (Antoniou, 1993; Neumann \& Zacher, 1998). These rocks have previously undergone extensive study in different areas (e.g. Maillot, 1979; Katsikatsos, 1980; Katsiavrias, 1991; Wagreich et al., 1996), but only few basinwide studies exist (e.g. Richter \& Müller, 1993; Piper \& Pe-Piper, 1980). Up to now, the chronostratigraphic framework is also poorly constrained.

This paper gives a preliminary summary of new data that contribute to the knowledge about age, composition and environment of the Mid-Cretaceous turbidite facies. Within the Pindos Zone of mainland Greece and the Peloponnese, 12 sections were recorded and sampled in detail (Fig.1). Numerous further outcrops were included in this study. Original logs and biostratigraphic data can be obtained from Neumann (1998).

\section{CHARACTERIZATION OF MID-CRETACEOUS LITHOLOGIES}

Throughout the working area, the Mid-Cretaceous is represented by a thin siliceous formation (few tens of m) sandwiched between thick successions of pelagic and turbiditic limestones of Upper Jurassic to lowermost Cretaceous and Upper Santonian to Paleocene ages (see inset in fig.1). The siliceous facies is comprised of thinbedded cherts, red clays and clayey marls with an apparent red/green cyclicity. Mud turbidites, radiolarian-sand layers and, locally, black shales are superimposed.

Regionally, in the upper part of the siliceous formation intercalations of gravity-displaced deposits appear. These sharply contrasting greenish turbidite sequences range in thickness from few $\mathrm{m}$ to $90 \mathrm{~m}$ at maximum. This clastic facies is characterized by the co-occurrence of carbonate and terrigeneous sediment within a vertical succession as well as within individual beds. Fig. 2 shows two simplified examples of tectonically backstripped sections in the Peloponnese with typical turbidite associations.

Biostratigraphic data of this study prove that shedding of these turbidite sequences took place in Middle Cenomanian to Early Santonian times (fig.3). Locally, siliciclastics occur in the earliest Cretaceous, e.g. in the area of Karpenission.

1. Dept. of Geology, Technical University of Munich, Arcisstr. 21, 80333 Munich, Germany 




Fig. 1: Tectonic sketch of the western Greek fold and thrust belt showing the location of the studied sections. The rough lithofacies distribution of the Mid-Cretaceous in the tectonically compressed Pindos nappe is indicated. (Additional data obtained from literature and the sheets of the Geological Map of Greece 1:50.000).

\section{TURBIDITE FACIES AND ASSOCIATIONS}

\subsection{SUMMARY OF DEPOSITIONAL TYPES}

The investigated sections contain a wide range of mass-flow deposits. Generally, the turbidite facies is made up by comparatively thin and finegrained beds. Coarse clastic facies, e.g. megabreccias, are missing. Bed thickness never exceeds $10 \mathrm{~m}$.

Debris-flow deposits (DF) are predominantly of calcareous origin and mainly form lenticular bodies with thicknesses up to $4 \mathrm{~m}$. Grain sizes reach $30 \mathrm{~cm}$. Clast- and matrix-supported breccias occur. Rarely, siliciclastic debris-flow deposits up to $1,5 \mathrm{~m}$ thick can be observed, which are characterized by a quartz-rich matrix and fragments of cherts, pelites and lutitic limestones.

Coarse grained turbidites (CTSgr) reach $7 \mathrm{~m}$ thickness at maximum. In most cases the coarse detritus is calcareous with the exception of cherts, silicified fragments and claystones. The upper Bouma divisions can be of siliciclastic origin. Gradational transitions between calcareous litho-/bioclasts and quartz are common. In few cases siliciclastics predominate (TSgr).

Sandy turbidites (terrigeneous: TS or calcareous: CTS) show thicknesses of some centimeters to $1,5 \mathrm{~m}$, commonly $20-60 \mathrm{~cm}$. They consist of calcareous and/or terrigeneous sediment. Internal turbidite features, like grading, ripple-cross and planar lamination are common. Erosive bases with coarse basal lags can be observed in coarser beds, sole marks and complete Bouma sequences are rare. Amalgamation of beds occurs. The siliciclastic turbidites show typical green or yellow weathering-colours.

Mud turbidites (TM) contain more than 50\% mud-sized material. Usually, they show minor thicknesses of some $\mathrm{cm}$, rarely up to $50 \mathrm{~cm}$. Their composition can be calcareous or terrigeneous. In the Pindos Mountains highly bituminous mudturbidites occur (Neumann \& Zacher, 1998). 




Fig.2: Examples of simplified logs of the Lower and Mid-Cretaceous facies of the Pindos Zone in the western Peloponnese ( $P 11$ and $P$ 8). The main turbidite facies are indicated. P11 shows a proximal setting with coarse and thick beds (orbitoline horizon) at the base of thinning upward sequences (channel fills).

\subsection{SUMMARY OF TURBIDITE ASSOCLATIONS}

The different types of mass-flow deposits are organized in specific packages. Vertical sequences can be simply composed of one bed type, e.g. sandy turbidites, but also display a variety of mass-flow types, partly mixed with other lithologies like cherts, pelites and pelagic limestones. Small-scale slumping occurs. The principle turbidite associations of the Cenomanian to Lower Santonian in the studied outcrops can be summarized as follows.

Siliciclastic:

Successions of sandy turbidites (TS) and shales

$4->40 \mathrm{~m}$

Calcareous:

Successions of calcareous turbidites (CTS, CTM)

few $\mathrm{m}$ to $80 \mathrm{~m}$

Successions of calcareous debris-flow deposits (DF) and coarse to medium-grained calciturbidites (CTSgr, CTS)

$>20 \mathrm{~m}$

Mixed calci- and siliciclastic:

Major thinning upward turbidite successions (TS, TM) with coarse

calcareous bases (CTSgr or DF)

up to $60 \mathrm{~m}$

Chaotic successions of calcareous and siliciclastic debris-flow deposits (DF)

and turbidites (CTSgr, CTS, TS, TM)

up to $15 \mathrm{~m}$ 
Coarser clastic facies and associations are described by Katsiavrias (1991) who mentions chaotic debris-flow deposits with up to $20 \mathrm{~m}$ thickness in the western Peloponnese, showing volcaniclastic matrix. Scandone (1971) even recognizes the occurrence of a large olistolithe of Triassic rocks in the Mid-Cretaceous of the Pindos Mountains in mainland Greece.

\subsection{FACIES AND AGE SIGNIFICANCE OF ORBITOLINE HORIZONS}

Orbitoline horizons display the coarse calcareous facies (DF and CTSgr). The new data make a restriction to two stratigraphic intervals within the lower Upper Cretaceous section likely. The orbitoline horizons are made up of either a single debris-flow/turbidite bed or of a clustering of several beds. Thicknesses of single beds range from less than $1 \mathrm{~m}$ to $7 \mathrm{~m}$. In the Pindos Mountains and the SW-Peloponnese a lower orbitoline horizon can be defined which, locally, forms the base of siliciclastic thinning-upward turbidite associations. Radiolaria in section P 2 prove a late Early to early Middle Cenomanian age (Neumann \& Zacher, 1998), which is supported by planktonic foraminifera (e.g. Favusella washitensis, Planomalina buxtorfi and Praeglobotruncana gibba). An upper, less pronounced orbitoline horizon occurs in the Late Turonian to Lower Coniacian interval, based on Marginotruncana- and Helvetoglobotruncana-faunas and radiolaria. Nannoplankton investigations in section P 4 support this age (CC13, Marthasterites furcatus zone), which is also reported by Wagreich et al. (1996). The beds contain orbitolines as free tests and/or as components of clasts. The orbitolines belong to the subfamilies Dictyoconinae and Orbitolininae. Identification down to species level was possible with Conicorbitolina conica (d'Archiac) (uppermost Albian to Middle Cenomanian).

It is tempting to speculate on a correlation of the orbitoline horizons with major event beds in adjacent zones, e.g. conglomeratic units in the Mid-Cretaceous Mesoautochthonous of the Pelagonian Zone as described by Richter et al. (1997).

\section{ON THE COMPOSITION OF THE TURBIDITE BEDS}

Siliciclastic and carbonate sediment occur in a variety of mixtures. Generally, carbonate debris ranges from mud-sized grains to pebbles of few tens of $\mathrm{cm}$, whereas the bulk of non-carbonate sediment is restricted to mud, silt- and sand-sized grains.

Carbonate detritus: The carbonate sediment is mainly composed of rudist debris $(20-80 \%$; hippuritids and radiolitids, e.g. Durania sp.) and varying amounts (10-90\%) of highly diverse lithoclasts of neritic and basinal facies. Further bioclasts include single benthic foraminifera (textulariids, orbitolinids, rotaliids and miliolids), planktonic foraminifera, echinoderms, poriferans, algae and others. Stratigraphic downcutting (shelf-edge and intrabasinal erosion) in the source area can be estimated to at least the Upper Albian and locally lowermost Cretaceous (Calpionella-bearing biomicrites).

Terrigeneous detritus: Regarding the proportion of principle grain types, the siliciclastic turbidites range from quartzarenites to moderately sorted carbonate-rich litharenites. The main non-calcareous grain type is subangular to sub-rounded quartz. Further contributors are cherts, sheet silicates like chlorite, muscovite and biotite, feldspar, and rock fragments of phyllites, quartzites, sandstones, pelites and few volcanics. Accessory minerals are chromite, glauconite, garnet and phosphates. Coarser fragments are rip-up clasts of silicified rocks, cherts, radiolarites and claystones. Plant debris occurs locally.

Ophiolitic debris: In the easternmost Peloponnese huge amounts (up to 20\%) of ophiolitic debris like chromite and fragments of serpentinites, radiolarites and diverse igneous rocks can be observed. Rounded and angular, finegrained volcanic rock fragments reach up to few $\mathrm{cm}$ in size in breccia deposits. Thin-section analysis shows a basic composition of microphenocrysts of plagioclase set in a groundmass of feldspars, altered pyroxenes and opaques. Calcite, sericite, chlorite and serpentine are common.

Investigations on the heavy mineral assemblages and their regional variation are currently in progress. Further data are given by Faupl et al. (1998). 


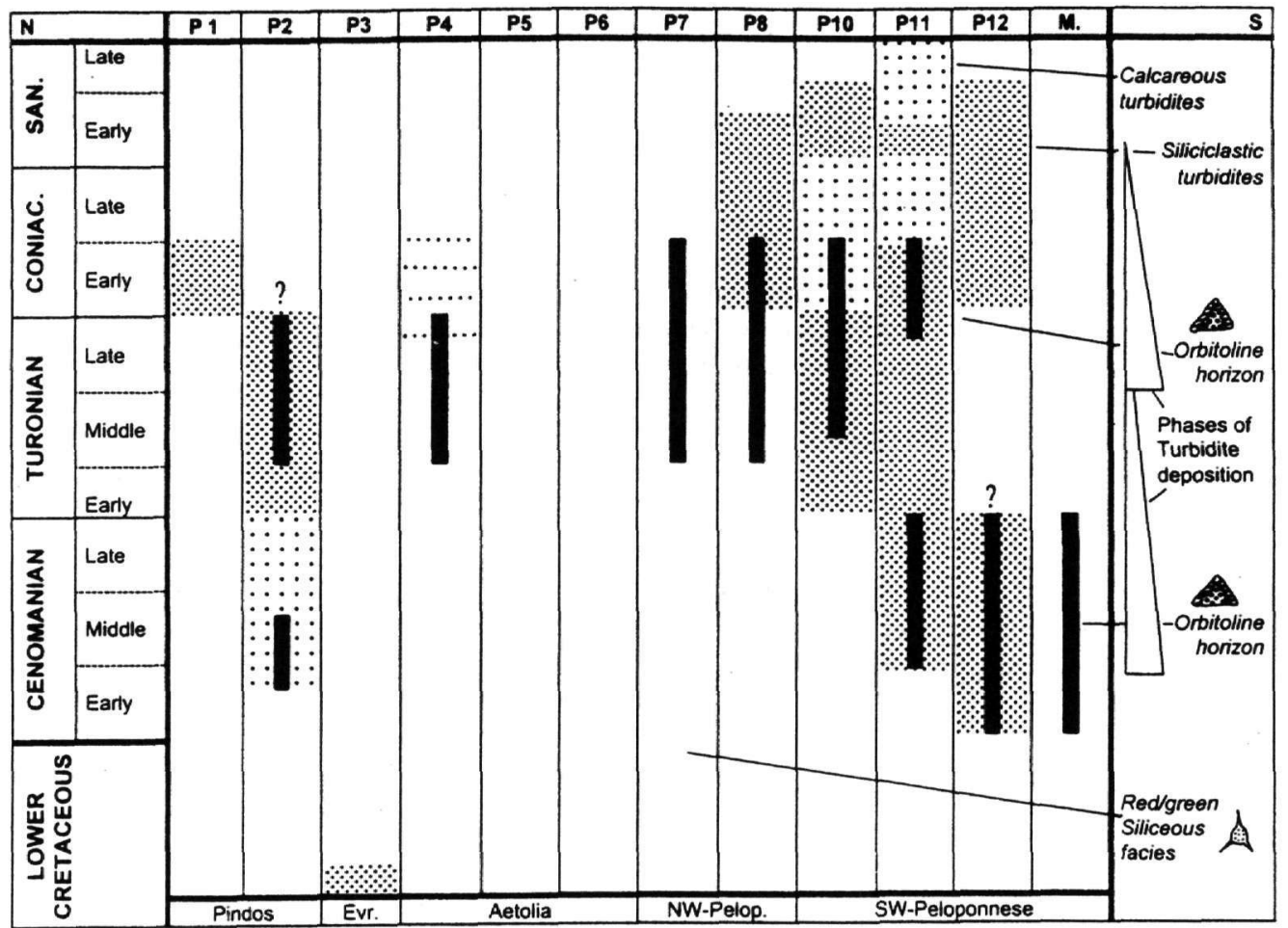

Fig. 3: Dating and comparison of Lower Cretaceous to Santonian clastics of the western Greek Pindos Zone. Length of bars shows the maximum stratigraphic ranges of the clastic depositional types, not the actual thickness. Biostratigraphic ages are based on planktonic foraminifera, radiolaria, redeposited fossils and nannoplankton.

(?: lack of observation; Evr.: Evritania; M.: Messenia)

\section{REMARKS ON PALEOCURRENTS AND ENVIRONMENT}

The available paleocurrent, facies and petrographic data point to the existence of three distinct areas with significant siliciclastic intercalations in the western Greek Pindos Zone (see fig.1). Except for single beds and dispersed detritus in calciturbidites, siliciclastics are nearly missing in the Aetolian Pindos (sections P 4, 5, 6). In the area of Karpenission (P 3) few sandstone beds occur as intercalations in Calpionella-bearing limestones of the earliest Cretaceous. Paleocurrent indicators comprise flute casts, dendritic ridge casts and groove casts, as well as ripple cross lamination. Rare findings make systematic interpretations difficult. However, a NNW-origin of turbidites in the central Pindos Mountains sections and a W to WSW-origin for the western Peloponnesian sections is likely. The orbitoline horizons match this pattern. The severely tectonized turbidites of the eastern Peloponnese offer no reliable paleocurrent indicators. The high proportions of ophiolitic debris, however, hint at sources to the east where abundant ophiolites occur (e.g. Huss et al., 1988). This overall pattern is consistent with the observed facies and thickness trends. Paleocurrent and heavy mineral data given by Piper $\&$ Pe-Piper (1980), Degnan \& Robertson (1998), Richter et al. (1993) and Faupl et al. (1998) support this view.

Thus axial as well as lateral terrigeneous input can be assumed for the western Greek Pindos Basin. The sediment was probably funnelled into the elongate basin via point sources providing an irregular distribution. The turbidite beds are organized into depositional units typical of distal submarine fans (lower fan facies after Normark, 1978). Major thinning-upward sequences resemble more proximal settings (channel fills), whereas fine-grained, thin turbidite successions are characteristic of the outer fan and basin plain. 


\section{CONCLUSIONS}

- Calci- and silicilastic deposits in the working area occur abruptly at the change of the Lower to the Middle Cenomanian and are restricted to the lower Upper Cretaceous in general.

- Mass wasting is most prominent in discrete phases (major redepositional events): The Cenomanian (upper Lower to lower Middle Cen.) and the Middle Turonian to Early Coniacian radiolarite facies can be punctuated by mass-flow deposits of the lower and upper orbitoline horizon.

- Different turbidites and turbidite associations with $90 \mathrm{~m}$ thickness at maximum can be distinguished and ascribed to different settings within distal submarine fan environments.

- Palaeocurrent and facies patterns point to a northern source for the outcrops in the Pindos Mountains of mainland Greece, but suggest questionable western sources for the Peloponnese except for the easternmost part. Shedding from the adjacent eastern (Sub-)Pelagonian Zone is assumed.

- Active faulting which is indicated by a complex paleotectonic evolution in adjacent zones (platform drowning, emergence episodes and flysch deposition) created an environment particularly favorable for gravity mass movements along the shelf breaks of the Pindos basin. Major collapses led to calcareous mass flows. Relative falls of sea-level could even trigger bypassing of terrigeneous sediment into the basin.

\section{ACKNOWLEDGEMENTS}

This paper presents results of parts of my Ph.D.-thesis sponsored by the German Research Foundation and the Free State of Bavaria. I am indebted to Prof. Dr. W. Zacher (Munich) and Prof. Dr. N. Fytrolakis (Athens) for supervision of my work. Helpful comments and advice were obtained from Dr. H. Risch (Munich), Prof. Dr. R. Schroeder (Frankfurt), Prof. Dr. F. Pomoni-Papaioannou (Athens) and Prof. Dr. A. Lekkas-Zambetakis (Athens). The Institute of Geology and Mineral Exploration (IGME, Athens and Tripolis) kindly permitted fieldwork.

\section{REFERENCES}

ANTONIOU, M. (1993): Contribution to the knowledge of the Olonos-Pindos Zone bituminous schists.- Mining and Metallurgical Annales, 3 (1): 85-96.

AUBOUIN, J. (1957): Essai de corrélations stratigraphiques en Grèce occidentale.- Bull. Soc. géol. Fr. (6), 7: 281-304.

DEGNAN, P.J. \& ROBERTSON, A.H.F. (1998): Mesozoic-early Tertiary passive margin evolution of the Pindos ocean (NW Peloponnese, Greece).- Sedimentary Geology, 117: 33-70.

DERCOURT, J., RICOU, L.E. \& VRIELYNCK, B. (eds.)(1993): Atlas Tethys, Palaeoenvironmental Maps.- 307 p., 14 maps, 1 pl.; Gauthier-Villars; Paris.

FAUPL, P., PAVLOPOULOS, A. \& MIGIROS, G. (1998): On the provenance of flysch deposits in the External Hellenides of mainland Greece: results from heavy mineral studies.- Geol. Mag., 135(3): 421-442

FLEURY, J.-J. (1975): Le „Premier Flysch du Pinde“, témoin de l'ensemble des événements orogéniques mésozoiques anté-Crétacé supérieur ayant affecté les Héllénides internes (Grèce). - C.R. Acad. Sc., 281 (D): 1459-1461.

FLEURY, J.-J. (1980): Les zones de Gavrovo-Tripolitza et du Pinde-Olonos (Grèce Continentale et Péloponnèse du Nord). Evolution d, une plateforme et une bassin dans le cadre alpin.- Soc. géol. Nord publ., 4: 651 pp..

GALLI, G. (1993): Temporal and Spatial Patterns in Carbonate Platforms.- Lecture Notes in Earth Sciences, 46: 325 pp.; Springer.

HUSS, A., GAITANAKIS, P. \& NEUGEBAUER, J. (1987/88): Der Ammonitico Rosso und seine sedimentäre und ophiolithische Bedeckung bei Ano Fanari (Argolis, Griechenland) - Tektonik einer obduzierten Mélange und seines Unterlagers.- Ann. Geol. des Pays hellén., 33: 85-112.

GUSIC, I. \& JELASKA, V. (1993): Upper Cenomanian-Lower Turonian sea-level rise and its consequences on the Adriatic-Dinaric carbonate platform.- Geol. Rundsch., 82: 676-686.

KATSIAVRIAS, N.A. (1991): Geological structure of the Lefkochori-Myli area - central Peloponnesus.- Dissertation Polytechnische Universität Athen, 173 S.; Athen.

KATSIKATSOS, G. (1980): Geological study of the Vassilikou-Ithomi area (Messenia, Peloponnesus).- Inst. Geol. Subsurf. Res., 197 S.; Athen.

MAILLOT, H. (1979): Etude sedimentologique du "Premiere Flysch" en Peloponnese occidental (Grece): La formation d'Andritsena.- Bull. Geol. Soc. Greece, 14 (1): 94-115.

NEUMANN, P. (1998): Ablagerungsprozesse, Event- und Biostratigraphie kreidezeitlicher Tiefwassersedimente 
der Tethys in der Olonos-Pindos-Zone Westgriechenlands.- Ph.D.-thesis Technical University Munich, 174 p., 42 fig.; Munich.

NEUMANN, P. \& ZACHER, W. (1998): New results on Radiolarian Biostratigraphy and Sedimentology of the Early Cretaceous to Turonian of the Pindos Zone in the Central Pindos Mountains (Mainland Greece).- Proceedings of the 8th Congress of the Geol. Soc. Greece, May 1998, Patras, Bull. Geol. Soc. Greece, 32 (2): 59 65.

NORMARK, E.R. (1978): Fan valleys, channels and depositional lobes on modern submarine fans: characters for recognition of sandy turbidite environments.- AAPG Bull., 62: 912-931.

PIPER, D.J.W. \& PE-PIPER, G. (1980): Was there a western (external) source of terrigeneous sediment for the Pindos zone of the Peloponnese (Greece).- N. Jb. Geol. Paläont. Mh., 1980: 107-115.

RENZ, C. (1955): Die vorneogene Stratigraphie der normalsedimentären Formationen Griechenlands.- Inst. Geol. Subsurf. Res., 637 S.; Athen.

RICHTER, D. \& M1/4LLER, C. (1993): Der „Erste Flysch“ in der Pindos-Zone (Griechenland)?.- N. Jb. Geol. Paläont. Mh., 1993 (4).

RICHTER, D., MIHM, A. \& M1/4LLER, C. (1997): Die pelagonischen Deckenreste auf dem Flysch des OstpindosSynklinoriums (Pindos-Zone) westlich des Iti-Gebirges (Mittelgriechenland).- Z. dt. geol. Ges., 148(2): $237-$ 246.

SCANDONE, P. (1971): Sulla posizione dei „Calcari di Peristeri“ (Pindos occidentale. Grecia).- Boll. Soc. Natur. in Napoli, 80: 139-145.

THIEBAULT, F., DE WEVER, P., FLEURY, J.J. \& BASSOULET, J.P. (1981): Précisions sur la série stratigraphique de la nappe du Pinde-Olonos de la presqu'ile de Koroni (Péloponnèse méridional - Grèce): l'age des Radiolarites - (Dogger - Crétacé supérieur).- Ann. Soc. Géol. Nord, 100: 91-105.

WAGREICH, M., PAVLOPOULOS, A., FAUPL, P. \& MIGIROS, G. (1996): Age and significance of Upper Cretaceous siliciclastic turbidites in the central Pindos Mountains, Greece.- Geol. Mag., 133: 325-331. 